\title{
A Case Study of How Embedding in Global Industrial Chain Effects on Chinese Enterprises' Radical Innovation
}

\author{
Wei Gao ${ }^{1, \text { a }}$, Jia Liu ${ }^{2, b}$ Zhi-xun Liü, c \\ ${ }^{1}$ State Grid Energy Research Institute, Beijing 102209, China \\ ${ }^{2}$ Development Research Center of China Geological Survey, Beijing 100037, China \\ agaoweisuda@163.com, bpamelacug@126.com, 'czhixunl@sina.com
}

\begin{abstract}
Keywords: Global industrial chain, Radical Innovation, Breakthrough innovation, The ability to integrating resources

Abstract. Radical innovation is an important opportunity for the technology backwardness enterprises to catch up with and surpass the leader. Through the exploratory case study, the study discovers the mechanism of how the Chinese wind power manufacturing enterprises realize the radical innovation by embedding in global industrial chain. The study finds that: 1) With the constant improvement of the embedding in global industrial chain level, the ability of integrating global industrial chain resources will be increased gradually; 2) The integration of global industrial chain resources includes integrating resource from suppliers technology and the market worldwide; 3) The ability of integrating global industrial chain resources has a positive effect on radical innovation performance.
\end{abstract}

\section{Introduction}

A large number of cases show that the radical innovation is the important opportunity for the enterprises to obtain Striding-across Way (Christensen, 1997) ${ }^{[1]}$, and it's also very important for the enterprises to maintain technological superiority leading position and improve the market competitiveness. It has been widely accepted by the scholars that the Radical innovation has greater dependence on the industrial chain (Johnsen, 2000; Tether, 2002; Petersen, Handfield \& Ragatz, 2005; Song, 2008; Adner, 2006) ${ }^{[2-6]}$. Despite the uncertainties, the researchers have generally agreed that the enterprises' innovation activities with upstream suppliers and downstream users can reduce risk and cost to a certain extent, and it also can get support from external technical, financial, and market (Chesbrough, 2003; West\& Gallagher, 2006) ${ }^{[7-8]}$. Look from the research trend, the innovation of the ecological environment and the whole industry chain of the study of innovation has become the important content of research in this field.

From the point of the existing literature, what's influence mechanism about embedded in the global industrial chain to radical innovation is not clearly. Some scholars have studied the network embeddedness impact on the performance of the enterprise's innovation, and found that the different embedding strength of the enterprise has different impact on their innovation (Uzzi, 1996; Bengtsson\& Solvell, 2004; Wu\& Wei, 2005) ${ }^{[9-11]}$. Although some scholars have tried to explain this problem from the view of learning ability of the enterprise and industry differences (Rowley, 2000)

${ }^{12]}$, but it's not enough to interpret the intrinsic mechanism and to explain the radical innovation from developing countries' enterprises which are in technical disadvantage.

In theory, the existing literature on the global industrial chain embedded research on the influence of Chinese enterprises radical innovation mechanism is not yet mature, so we need to explore the research blank. In reality, China's emerging enterprises have begun to integrate global resources to build core competitive advantages by radical innovation strategy rely on their own advantages. Therefore, through the case study, this article attempts to analyze how China's enterprises embed the global industrial chain to promote their resource integration ability, and then affect their radical innovation. Figure 1 is the default theory of case study. 


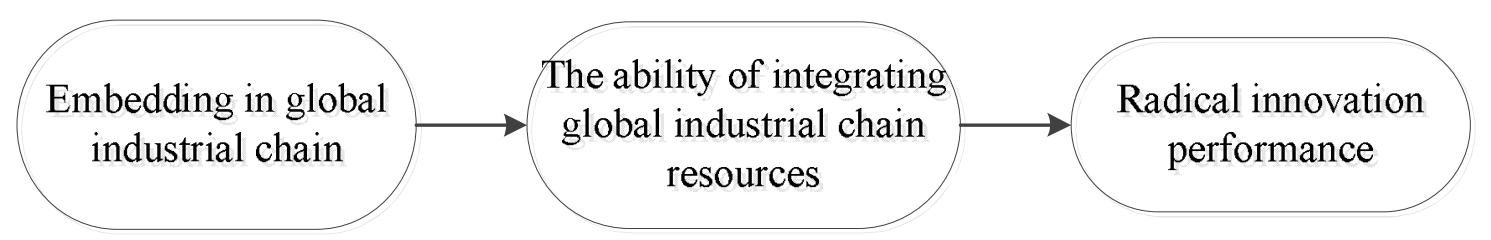

Fig.1 The default theory of case study

\section{Case study method}

\section{Choose the right method of case study}

Case study is a kind of important research method which is widely used in sociology, economics, political science, psychology, management and other fields. According to different research purposes, case study is generally divided into exploratory case study, descriptive case studies, explanatory case studies and valuation case studies (Eisenhardt, 1989) ${ }^{[13]}$. Table 3-1 lists the main research purpose and research focus of different kinds of case studies.

Table 1 the main research purpose and research focus of different kinds of case studies

\begin{tabular}{|c|l|l|}
\hline $\begin{array}{c}\text { The type of case } \\
\text { study }\end{array}$ & \multicolumn{1}{|c|}{ Research purpose } & \multicolumn{1}{|c|}{ Research emphasis } \\
\hline Descriptive case study & $\begin{array}{l}\text { to make an accurate description of the whole } \\
\text { incident }\end{array}$ & $\begin{array}{l}\text { to make a detailed } \\
\text { description of events }\end{array}$ \\
\hline $\begin{array}{c}\text { Explanatory case } \\
\text { study }\end{array}$ & $\begin{array}{l}\text { to summarized the special phenomenon, to } \\
\text { explore the regularity of change, and explain } \\
\text { causal relationship }\end{array}$ & $\begin{array}{l}\text { to give theoretical } \\
\text { explanation to the event }\end{array}$ \\
\hline $\begin{array}{c}\text { Evaluative case study } \\
\text { to express their views and opinions }\end{array}$ & $\begin{array}{l}\text { put forward some views on } \\
\text { the evaluation }\end{array}$ \\
\hline $\begin{array}{c}\text { Exploratory case } \\
\text { study }\end{array}$ & $\begin{array}{l}\text { Try to use a new Angle, new ideas, new model } \\
\text { to explain some phenomenon }\end{array}$ & $\begin{array}{l}\text { put forward the theoretical } \\
\text { assumptions }\end{array}$ \\
\hline
\end{tabular}

*Resource: K.M. Eisenhardt: Building theories from case study research, Academy of management review, Vol. 14(1989), p. 532-550

The purpose of this research is to explore how the enterprises integrate various resources through actively embedded in the global industrial chain to enhance the organization's radical innovation performance. In the field of radical innovation research, from the perspective of embedded in global industrial chain is that which from a new Angle to evaluate a phenomenon, so the exploratory case study is suitable for the research.

The research steps

It is generally believed that there should be eight steps for the exploratory case study (Eisenhardt 1989) ${ }^{[13]}$. This study follows the eight steps which show in Table 2. 
Table 2 The steps of case study

\begin{tabular}{|c|c|c|c|}
\hline \multicolumn{2}{|c|}{ Step } & Activity & Reacon \\
\hline \multirow{3}{*}{$\begin{array}{l}\text { Preparation } \\
\text { stage }\end{array}$} & $\begin{array}{c}\text { Start the case } \\
\text { study }\end{array}$ & $\begin{array}{l}\text { Definition of research } \\
\text { question; Possibly a priori } \\
\text { constructs; } \\
\text { Nelther theory nor hypotheses }\end{array}$ & $\begin{array}{l}\text { Focuses efforts; Provides better } \\
\text { grounding of construct measures; } \\
\text { Retains theoretical flexibility }\end{array}$ \\
\hline & $\begin{array}{l}\text { Choose to } \\
\text { study } \\
\text { principle }\end{array}$ & $\begin{array}{l}\text { Specified population; } \\
\text { Theoretical, not random, } \\
\text { sampling }\end{array}$ & $\begin{array}{l}\text { Constrains extraneous variation and } \\
\text { sharpens external validity; Focuses } \\
\text { efforts on theoretically useful cases i.e., } \\
\text { those that replicate or extend theory by } \\
\text { filling conceptual categories }\end{array}$ \\
\hline & $\begin{array}{l}\text { Craftlng } \\
\text { Instrument } \\
\text { and } \\
\text { Protocols }\end{array}$ & $\begin{array}{l}\text { Multiple data collection } \\
\text { methods; Qualitative and } \\
\text { quantitative data combined } \\
\text { Multiple investlgators }\end{array}$ & $\begin{array}{l}\text { Strengthens grounding of theory by } \\
\text { triangulation of evidence; Synergistic } \\
\text { view of evidence; Fosters divergent } \\
\text { perspectives and strengthens grounding }\end{array}$ \\
\hline \multirow{3}{*}{$\begin{array}{l}\text { Execution } \\
\text { phase }\end{array}$} & $\begin{array}{l}\text { Entering the } \\
\text { Fleld }\end{array}$ & $\begin{array}{l}\text { Overlap data collection and } \\
\text { analysis, Including field } \\
\text { notes; Flexible and } \\
\text { opportunistic data collection, } \\
\text { methods }\end{array}$ & $\begin{array}{l}\text { Speeds analyses and reveals helpful } \\
\text { adjustments to data collection; Allows } \\
\text { investigators to take advantage of } \\
\text { emergent themes and unique case } \\
\text { features }\end{array}$ \\
\hline & $\begin{array}{c}\text { Anaiyzlng } \\
\text { Data }\end{array}$ & $\begin{array}{l}\text { Withln-case analysls; } \\
\text { Cross-case pattern search } \\
\text { using divergent techniques }\end{array}$ & $\begin{array}{l}\text { Gains famillarity with data and } \\
\text { preliminary theory generation; Forces } \\
\text { investigators to look beyond initlal } \\
\text { impressions and see evidence through } \\
\text { multiple lenses }\end{array}$ \\
\hline & $\begin{array}{l}\text { Shaping } \\
\text { Hypotheses }\end{array}$ & $\begin{array}{l}\text { Iterative tabulation of } \\
\text { evidence for each construct; } \\
\text { Repllcatlon, not sampling, } \\
\text { logic across cases; Search } \\
\text { evldence for "why" behind } \\
\text { relationships }\end{array}$ & $\begin{array}{l}\text { Sharpens construct definition, validity, } \\
\text { and measurability; Confirms, extends, } \\
\text { and sharpens theory; Builds Internal } \\
\text { valldity }\end{array}$ \\
\hline \multirow[t]{2}{*}{$\begin{array}{l}\text { Dialogue } \\
\text { phase }\end{array}$} & $\begin{array}{l}\text { Enfolding } \\
\text { Literature }\end{array}$ & $\begin{array}{l}\text { Comparison with conflicting } \\
\text { literature; Compare with } \\
\text { similar literature }\end{array}$ & $\begin{array}{l}\text { Builds internal validity, raises } \\
\text { theoretical level, and sharpens construct } \\
\text { definitions; Sharpens generallzability, } \\
\text { improves construct definition, and } \\
\text { raises theoretical level }\end{array}$ \\
\hline & $\begin{array}{l}\text { Reaching } \\
\text { Closure }\end{array}$ & $\begin{array}{l}\text { Theoretical saturation when } \\
\text { possible }\end{array}$ & $\begin{array}{l}\text { Ends process when marglnal } \\
\text { Improvement becomes small }\end{array}$ \\
\hline
\end{tabular}

*Resource: K.M. Eisenhardt: Building theories from case study research, Academy of management review, Vol. 14(1989), p. 532-550

\section{Case Selection}

Because of the huge difference of characteristics among enterprises, the mode of multiple case

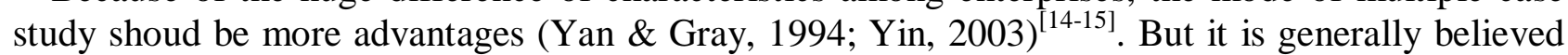
to have the following characteristics that can be used in single case study (Eisenhardt, 1989) ${ }^{[13]}: 1$ ) critical cases of the mature theory; 2) the extreme or unique case; 3) exposure type case. This study aims to explore the internal mechanism of Chinese entreprise's radical innovation, build a conceptual framework preliminary, so this study is appropriate for single case model.

On the basis of above analysis, the paper takes several factors into account before choosing the type case:1) Limiting the case in high-end equipment manufacturing and new energy industry, because the industrial chain of these is longer than other emerging industries', and it also can reduce the extraneous variation to some extent (Yan \& Gray, 1994) ${ }^{[14]}$; 2) Choosing the representative 
enterprise with radical innovation strictly; 3) Selecting case is not random, but takeing the availability of data and information and the representative of the enterprise into account.

\section{Research process}

\section{Data collection process}

The research collects data mainly through interview and public documentation. In the interview, the researchers talked about the radical innovation performance, innovation strategy and the cooperation with upstream and downstream with the prepared interview outline with high-level personnel. On the basis of the consent of the respondents, we recorded the conversation by tape, and made further arrangement within 24 hours after the interview.

The research choose interview respondents follow these standards: 1) Must be over 3 years working experience in the enterprise; 2) Must be familar with enterprise's R\&D and product management; 3) Must be the enterprise's senior supervisor or above; 4) The one who must agree to carry out the research, and accept the follow-up interviews. Three days after the interview, The researchers made a further communication and confirmation about the interview information, and perfected the related information fully. At the same time, the researchers paid attention to the Internet, newspapers, magazines and other channels to collect the enterprise management interviews news, product introduction, the annual reports, enterprise publicity materials such as public information as further supplement of the interview.

\section{Data analysis process}

Base on the basis of former presupposes, the researchers discussed and classified the data with related experts. Ultimately, The data was divided into several categories, including enterprise's radical innovation, the process of embeding in global industrial chain and how the enterprise integrated resources from global industrial chain. Then, the researchers summarized the case to further expand and refined the existing theory.

\section{Overview of "Firm A"}

Firm A is founded in 1998 with 100 million yuan of the registered capital, and which is the high and new technology enterprises in xinjiang uygur autonomous region. Firm $\mathrm{A}$ is also the leading wind power equipment manufacturing enterprises and the overall solution provider of wind power. The company has independent intellectual property rights of direct-drive permanent magnet technology, represents the most growth prospects in the field of global wind power technical route, and it has been honored with the "world's most innovative ability top 50 enterprises" twice by the journal of Technology review of Massachusetts institute of technology. The company is the largest direct-drive permanent magnet fan manufacturing enterprise in the world now. It has united a group of high level of manufacturing, $R \& D$ enterprise to formed a team in wind power equipment manufacturing industry which is the important condition for China's wind power equipment to achieve industrialization.

\section{Case analysis}

\section{The radical innovation of enterprise}

Traditional wind turbines is composed of blades, gear box, generator, inverter, control system, bearing and spindle, base, tire, and so on. All of them, gear box is an important part in wind turbines manufacturing for the most difficulty of $R \& D$, Manufacturing and assembly. Compared with traditional wind turbines, direct-drive permanent magnet wind turbines is a radical innovation. The characteristics of two types of wind turbines are shown in Table 3. 
Table 3 The difference between direct-drive permanent magnet turbine and the traditional one

\begin{tabular}{|c|c|c|}
\hline & Direct-drive permanent magnet turbine & Traditional gear turbine \\
\hline Reliability & $\begin{array}{l}\text { With the direct-drive technology, it can save the } \\
\text { gearbox accessories, simplifies the transmission } \\
\text { structure, improve the reliability of the unit. At the } \\
\text { same time, the unit runs at low speed, rotating parts } \\
\text { is less, and the reliability is higher. }\end{array}$ & $\begin{array}{l}\text { Constantly running } 24 \text { hours a } \\
\text { day makes the gear box be the } \\
\text { most easily to fail in wind } \\
\text { turbine. }\end{array}$ \\
\hline Maintainability & $\begin{array}{l}\text { Can reduce the amount of machine parts of wind } \\
\text { power generation group, avoid gear box oil change } \\
\text { regularly, reduce the operation maintenance cost. }\end{array}$ & $\begin{array}{l}\text { The struc } \\
\text { it is diff } \\
\text { remote ar }\end{array}$ \\
\hline $\begin{array}{l}\text { Efficiency of } \\
\text { power } \\
\text { generation }\end{array}$ & $\begin{array}{l}\text { Impellers drive permanent magnet generators } \\
\text { directly without electro-magnetic, which reduce the } \\
\text { power loss; there is no middle part such as gear } \\
\text { box, and the transmission chain is short which can } \\
\text { reduce the transmission loss with more efficient } \\
\text { operation. }\end{array}$ & $\begin{array}{l}\text { Affected by number, quality, } \\
\text { speed and other factors of the } \\
\text { gear, and also consumes some } \\
\text { energy at the same time. }\end{array}$ \\
\hline & & \\
\hline
\end{tabular}

Source: From the interview and corporate's websites

Firm $\mathrm{A}$ is the world's largest direct-drive permanent magnet wind turbine at present, and there has more than $10 \mathrm{GW}$ direct-drive permanent magnet generator been completed all over the word. The distribution of the project is in 18 provinces and autonomous regions of China and 17 countries across six continents. It has received 14 projects in United States across 10 states. Up to 2014, Firm A had got more than $300 \mathrm{MW}$ project in America market, and the total capacity had over $500 \mathrm{MW}$ in overseas markets.

\section{Embedding in global industrial chain}

Reviewing the development process of Firm A, it carried out the strategy of "promoting internationalization base on localization" to occupy the international market. Firm A has established more than 10 branches and offices abroad which covers North America, South America, Australia, Europe and Africa market. The globalization business layout is becoming mature and perfect increasingly.

In 2003, Firm A started to cooperate with Vensys to introduce direct-drive permanent magnet technology. In 2004, the company began to make direct-drive permanent magnet megawatt fan joint design with Vensys. In 2006, it set up wholly owned subsidiary in Germany. At the same year, it started to cooperate with British GH, Dutch Macll, Germany Vensys and other international academic research institutions and design companies.

In 2008, Firm A completed $70 \%$ stake acquisition of Germany Vensyse, and built the construction of $R \& D$ center in Beijing, xinjiang and Germany which meaned that the product internationalization development platform had been established. Firm A combined the China's manufacturing and Germany's design organically, and it also get the concept, style, methodology, etc. of the Germany company. The deal marked Firm A become the China's first enterprise to have completely independent R\&D capacity of wind power equipment manufacturers. At the same time, it opened the gate for the company's products to enter the international market space.

Up to 2014, Firm A had set up more than a dozen overseas subsidiaries, covering North America, South America, Australia, Africa, Europe and other key overseas markets. A total of more than 200 units had been or would be installed in the United States, Cuba, Australia, Ethiopia, Pakistan as well as Cyprus and many other overseas markets. The cooperative enterprise from global industrial chain are showed in Table 4. 
Table 4 The cooperative enterprise from global industrial of Firm A

\begin{tabular}{|c|c|c|c|c|}
\hline Date & $\begin{array}{l}\text { Cooperative } \\
\text { enterprise }\end{array}$ & Position & Content & Meanings \\
\hline $\begin{array}{l}\text { February } \\
2007\end{array}$ & LM Glasfiber & Upstream & $\begin{array}{l}\text { Supply } \\
\text { blade }\end{array}$ & $\begin{array}{l}\text { Gets LM's strong support in product } R \& D \text {, } \\
\text { quality control and risk prevention. }\end{array}$ \\
\hline 2008 & VENSYS & Upstream & Acquisition & $\begin{array}{l}\text { Gets direct-drive permanent magnet motor } \\
\text { technology }\end{array}$ \\
\hline May 2012 & $\begin{array}{l}\text { Timken } \\
\text { Company }\end{array}$ & Upstream & $\begin{array}{l}\text { Components } \\
\text { and parts }\end{array}$ & $\begin{array}{l}\text { One of the steps to continue to expand the } \\
\text { market share of USA }\end{array}$ \\
\hline $\begin{array}{l}\text { October } \\
2012\end{array}$ & PTC USA & $\begin{array}{l}\text { Technical } \\
\text { service }\end{array}$ & $\begin{array}{l}\text { Access } \\
\text { technology }\end{array}$ & $\begin{array}{l}\text { Enables enterprises to optimize the } \\
\text { management and evolution in the life of the } \\
\text { product within a single environment }\end{array}$ \\
\hline $\begin{array}{l}\text { December } \\
2012\end{array}$ & $\begin{array}{l}\text { The Three } \\
\text { Gorges } \\
\text { Corporation }\end{array}$ & Downstream & $\begin{array}{l}\text { Joint } \\
\text { development }\end{array}$ & $\begin{array}{l}\text { The first project in Pakistan and South Asia } \\
\text { market, and is also the first business } \\
\text { cooperation with the three gorges group in } \\
\text { overseas. }\end{array}$ \\
\hline $\begin{array}{l}\text { January } \\
2013\end{array}$ & $\begin{array}{l}\text { Volkswind } \\
\text { USA }\end{array}$ & Downstream & Acquisitions & Expands market share in North America \\
\hline $\begin{array}{c}\text { February } \\
2013 \\
\end{array}$ & Mainstream & Downstream & $\begin{array}{l}\text { Develope } \\
\text { wind field }\end{array}$ & Enters Chile market \\
\hline $\begin{array}{l}\text { September } \\
2013\end{array}$ & EGCO & Downstream & $\begin{array}{l}\text { Provide the } \\
\text { fan }\end{array}$ & Enters the southeast Asia market \\
\hline $\begin{array}{l}\text { September } \\
2013\end{array}$ & $\begin{array}{l}\text { China South } \\
\text { Locomotive }\end{array}$ & Upstream & Turbine & $\begin{array}{l}\text { CSR gets direct-drive permanent magnet } \\
\text { motor technology }\end{array}$ \\
\hline $\begin{array}{l}\text { September } \\
2013\end{array}$ & $\begin{array}{c}\text { German Fleur } \\
\text { Group }\end{array}$ & Midstream & $\begin{array}{l}\text { Personnel } \\
\text { training }\end{array}$ & $\begin{array}{l}\text { Personnel training, technology platform } \\
\text { building, the new product project } \\
\text { development process and service solutions }\end{array}$ \\
\hline
\end{tabular}

Source: From the interview and the corporate's websites

\section{Integrating the resources from global industrial chain for innovation Integrating global technology resources}

In 2005, Firm A introduced the first 1.2 MW permanent magnet unit, and achieved the acquisition of Vensys' $70 \%$ stake in 2008, and then became the first company with R\&D ability of China's wind power manufacturers. It established the greater $R \& D$ system which broke through the limit of the area through making joint R\&D in xinjiang, Beijing and Germany in 2010. The design from Germany's R\&D center faced to international market, and that from beijing $R \& D$ center provided the product for China's market, and the xinjiang $R \& D$ center provide platform for all of the $R \& D$ center.

In R\&D management, Firm A made German R\&D team still has a 30\% stake to maintain Vensys independence and whole $\mathrm{R} \& \mathrm{D}$ ability to retain excellent technical personnel though it had the ability to buy all. Firm A had hold the point that the technology must be in the hands of the Chinese, then it has changed the option and argues that the people is more valuable than the capital, it's a good choice for the foreign employees to stay to work hard when they fell fully be respected. Through the acquisition, Firm A has changed the innovation idea, it don't care where the company registration is and whether the technology foreigners master.

Firm A continues to strengthen the talent localization strategy to strive to realize the internationalization of human resources. It even encourages the doctors and masters to join in after they graduated through various channels. The company has only one Chinese in the United States, others are local talents. Up to 2014, Firm A had more than 4000 employees around the world, including the talents from famous companies such as GE, Siemens, Huawei, SKF management talent and so on. 


\section{Integrating global market resources}

As one of the earliest China's enterprises go abroad, Firm A not only has made remarkable achievements in the United States, Australia in wind power mature market, but also has made efforts to enter South America, Africa and other emerging markets actively, and has got lots of orders in Asia except China. Firm A made a deal with Electricity Generating Public Company Limited to develop the Southeast Asia market, joined Mainstream to develop the first phase of the wind farm project of Ckani in northern Chile. The Shady Oaks project in the United States Illinois, the Adama projects in Africa and the Mortons Lane project in Australia are also in smooth progress.

Firm A absorbed the internationalization management experience in exploiting the overseas markets. It was difficult to enter India market directly because of the high barriers. But Firm A obtained the stability market through selling technology only, and let the people who were familiar with the local market do the market. As the same pattern, the market share was the fourth of Argentina. In the United States market, there wad a special job of market analysis to feedback the local market information under the stress of orders and performance. It was conducive to the transmission of information for hiring the local workers. The downstream partners of Firm $\mathrm{A}$ in international market in 2010-2013 is in Table5.

Table5 The downstream partners of A companies in the international market in 2010-2013

\begin{tabular}{|c|c|c|c|c|c|}
\hline Year & Nation & Partners & $\begin{array}{l}\text { Amount of } \\
\text { the turbine }\end{array}$ & $\begin{array}{l}\text { Specifications } \\
\text { of the turbine }\end{array}$ & $\begin{array}{l}\text { The total } \\
\text { capacity }\end{array}$ \\
\hline \multirow{5}{*}{2010} & Brazil & IMPSA wind & 16 & $1.5 \mathrm{MW}$ & $24.0 \mathrm{MW}$ \\
\hline & India & ReGen & 66 & $1.5 \mathrm{MW}$ & $99.0 \mathrm{MW}$ \\
\hline & German & VENSYS & 1 & $2.5 \mathrm{MW}$ & $2.5 \mathrm{MW}$ \\
\hline & German & VENSYS & 1 & $1.5 \mathrm{MW}$ & $1.5 \mathrm{MW}$ \\
\hline & Poland & VENSYS & 1 & $1.5 \mathrm{MW}$ & $1.5 \mathrm{MW}$ \\
\hline \multirow{8}{*}{2011} & Brazil & IMPSA Wind & 148 & $1.5 \mathrm{MW}$ & $222.0 \mathrm{MW}$ \\
\hline & India & ReGen & 198 & $1.5 \mathrm{MW}$ & $297.0 \mathrm{MW}$ \\
\hline & Sri Lanka & ReGen & 7 & $1.5 \mathrm{MW}$ & $10.5 \mathrm{MW}$ \\
\hline & German & VENSYS & 9 & $1.5 \mathrm{MW}$ & $13.5 \mathrm{MW}$ \\
\hline & Cyprus & VENSYS & 21 & $1.5 \mathrm{MW}$ & $31.5 \mathrm{MW}$ \\
\hline & The USA & VENSYS & 4 & $1.5 \mathrm{MW}$ & $6.0 \mathrm{MW}$ \\
\hline & Poland & VENSYS & 5 & $1.5 \mathrm{MW}$ & $7.5 \mathrm{MW}$ \\
\hline & Canada & VENSYS & 1 & $1.5 \mathrm{MW}$ & $1.5 \mathrm{MW}$ \\
\hline \multirow{5}{*}{2012} & Brazil & IMPSA Wind & 25 & $1.5 \mathrm{MW}$ & $37.5 \mathrm{MW}$ \\
\hline & The USA & $\mathrm{GE}$ & 96 & $1.5 \mathrm{MW}$ & 144.0 MW \\
\hline & The USA & GE & 7 & $2.5 \mathrm{MW}$ & $17.5 \mathrm{MW}$ \\
\hline & Ecuador & GE & 11 & $1.5 \mathrm{MW}$ & $16.5 \mathrm{MW}$ \\
\hline & Australia & OneWind & 13 & $1.5 \mathrm{MW}$ & $19.5 \mathrm{MW}$ \\
\hline \multirow{6}{*}{2013} & German & VENSYS & 13 & $1.5 \mathrm{MW}$ & $19.5 \mathrm{MW}$ \\
\hline & Poland & VENSYS & 6 & $1.5 \mathrm{MW}$ & $9.0 \mathrm{MW}$ \\
\hline & Egypt & VENSYS & 2 & $1.5 \mathrm{MW}$ & $3.0 \mathrm{MW}$ \\
\hline & German & VENSYS & 4 & $2.5 \mathrm{MW}$ & $10.0 \mathrm{MW}$ \\
\hline & India & ReGen & 227 & $1.5 \mathrm{MW}$ & $340.5 \mathrm{MW}$ \\
\hline & Sri Lanka & ReGen & 8 & $1.5 \mathrm{MW}$ & $12.0 \mathrm{MW}$ \\
\hline
\end{tabular}

Source: Sorting the data from the corporate's websites

Integrating supplier resources at home and abroad

At the beginning of the company, there was very few parts suppliers, it not only had to design the accessories themself, but also had to develop suppliers. Later, Firm A chose the direct-drive permanent magnet technology route which meant the scope of the supplier was more narrow. For one hand, Firm A needed to take more effort to support suppliers. On the other hand, it had to seek reliable supplier resources from abroad. Because the wind power industry was emerging industry, 
the development of the industry chain was not complete in early stage. It was a necessary condition for firm A to develop and integrate the upstream suppliers.

First, fostering the suppliers. When the suppliers were in trouble, Firm A provided technical or financing support to let them be on track as soon as possible. For example, Firm A took the advantage of capital to help the key parts suppliers to improve productivity by increasing proportion of advance payment, building and renting blade factory building, etc. Firm A also established long-term strategic partnership through the opportunity of a large number of purchasing with the suppliers to guarantee the supply of them. Firm A even took more attention to the technology of motor, electric control system of key parts, and participated in parts production on the premise of improving quality and reducing cost.

Second, creating conditions to attract the suppliers to join. At the start-up period, Firm A required very high quality suppliers, but the well-known international companies were reluctant to take risks to build factory in local. In order to attract the world's largest blade manufacturers - LM company, Firm A built the factory for LM in xinjiang for free. The high quality blade from LM played an important role in the development of enterprises.

Third, establishing high quality cooperation through emotional links. With the key technology of wind power and the supplier's support, Firm A has kept a rapid development for many years. By 2014, Firm A had established cooperative relations with 88 well-known suppliers in the world, including ABB, Siemens and Infiniti. (Table 6). 
Table 6 The main supplier list of Firm A

\begin{tabular}{|c|c|l|}
\hline The main supplier & Nation & \multicolumn{1}{c|}{ Main business areas } \\
\hline TIMKEN & American & high precision bearing \\
\hline ABB & Switzerland & High-power inverter, the control system \\
\hline Siemens & Germany & The machine parts \\
\hline Infineon Technologies & Germany & Semiconductor chips \\
\hline CSR & China & The generator \\
\hline SKF & Sweden & Bearing \\
\hline Dupont & American & High temperature resistant, oil filled transformer \\
\hline LM & Denmark & The glass fiber blades \\
\hline The Switch & Finland & Electrical transmission equipment \\
\hline INA, FAG and LUK & Germany & Bearing \\
\hline BONFIGLIOLI & Italy & Reducer \\
\hline
\end{tabular}

Source: From the interview and corporate's websites

\section{Causal relationship about the variables}

In order to reveal the possible causal relationship among embedding in global industrial chain, the resource integration ability and radical innovation, the paper takes the following strategies to analyze the case.

First, identifying the position of Firm A in global global industrial chain and the relationship between Firm A and its cooperative enterprises in different development period. Second, analyzing whether the resource integration ability and radical innovation performance has changed dramatically or not before and after the degree internationalization of Firm A has changed significantly. If so, the result can explain the causal relationship that the embedding in global industrial chain affects the ability of resource integration and radical innovation. The enterprise's development stage and representative events are showed in table 7.

Table 7 The analysis of enterprise's development stage and representative events

\begin{tabular}{|c|c|l|c|c|c|}
\hline Phase & Year & Representative event & $\begin{array}{c}\text { Embedding } \\
\text { in global } \\
\text { industrial } \\
\text { chain }\end{array}$ & $\begin{array}{c}\text { Resource } \\
\text { integration } \\
\text { ability }\end{array}$ & $\begin{array}{c}\text { Radical } \\
\text { innovation } \\
\text { performance }\end{array}$ \\
\hline $\begin{array}{c}\text { Phase } \\
\text { one }\end{array}$ & Before 2001 & $\begin{array}{l}\text { Start the transformation from } \\
\text { scientific research to market }\end{array}$ & $\begin{array}{c}\text { Lower } \\
\text { degree }\end{array}$ & Lower leavel & Lower leavel \\
\hline $\begin{array}{c}\text { Phase } \\
\text { two }\end{array}$ & $2001 \sim 2006$ & $\begin{array}{l}\text { Set up branches in Germany, } \\
\text { and list on the shenzhen stock } \\
\text { exchange. }\end{array}$ & $\begin{array}{c}\text { General } \\
\text { degree }\end{array}$ & General leavel & Lower leavel \\
\hline $\begin{array}{c}\text { Phase } \\
\text { three }\end{array}$ & $2007 \sim 2008$ & $\begin{array}{l}\text { Acquisit VENSES, get the } \\
\text { direct-drive permanent magnet } \\
\text { technology, wind turbines } \\
\text { exports for the first time }\end{array}$ & $\begin{array}{c}\text { Higher } \\
\text { degree }\end{array}$ & Higher leavel & General \\
leavel
\end{tabular}

Source: From the interview and corporate's websites

In phase one, transfering from a research institute, Firm A mastered the $600 \mathrm{KW}$ blower manufacturing techniques through its own technology accumulation, whole machine import and technology import. At this stage, the link of Firm A to the global industrial chain was limited to the primary stage such as importing technology and buying the whole turbine for the power plant construction. The domestic market was in the initial stage, and the foreign market was blank, so both of the degree of embedding in global industrial chain and the leveal of resources integration ability of global supply chain were low. Its technology derives from its own accumulation and 
technology import which is in the period of chasing and imitating the mature technology, so the radical innovation performance was low.

In phase two, Firm A set up a subsidiary in Germany which worked on large wind turbine R\&D, technical consulting, technical services, import and export agent about all the law allows. At this stage, Firm A continued to strengthen the international strategy, set up subsidiary abroad to deepen international cooperation and get in touch with more advanced technology, so the degree of embedding in global industrial chain and the resources integration ability of global supply chain were improved. Because Firm A had not grasped direct-drive permanent magnet technology truly at this stage, its radical innovation performance level was still in low.

In phase three, Firm A acquired VENSYS, and obtained direct-drive permanent magnet technology, and then completed the construction of R\&D center of Beijing, xinjiang, Germany, Hong Kong. It had become the first domestic wind power machine manufacturers with completely independent $R \& D$ capacity and intellectual property rights, and it had developed the international market with the downstream partners successly at the same time. At this stage, Firm A continued to deepen the international strategy, strengthened the connection with the enterprises in global industrial chain, and it also could expand its influence through integrating the technology, market and suppliers resources of global industrial chain. Because Firm A mastered the new generation technology of wind power turbine, the radical innovation performance was also increased.

In stage four, Firm A continues to improve and strengthen its technology advantage. On one hand, Firm A continues to develope direct-drive permanent magnet motor. On the other hand, it makes effort to expand its market share, deepen the cooperation with the industrial chain upstream and downstream enterprises, strengthen the resources integration ability and the industry leading position. Before 2007, the nomber of the companies which apply direct-drive technology was only two include Firm A. But with the gradually mature of direct-drive permanent magnet technology, wind energy giants such as Siemens, GE and other companies have also dabble in the field of permanent magnet direct-drive, and the technology advantage has began to appeared especially on the offshore wind. With the technology advantage of its frist into, Firm A has become the leader in wind power industry. Therefore, the embedding in global industrial chain, resources integration ability of industrial chain and the radical innovation has reached the high leavel.

The case shows that, from the process of introducing foreign technology to produce the first wind turibine to grow up to be the leader of the industry, the sucess of Firm A depends on its integration into the global industrial chain based on its own advantages and the integration of the global industrial chain resources.

It is propitious to promote the radical innovation for enterprise to gain complementary, diversity and heterogeneity knowledge from outside the area (Freeman, 1998) ${ }^{[16]}$. Firm A strengthened its technical strength through mergers and acquisitions, technology transfer, cooperative development on global scale, and also laies the foundation for its radical innovation.

The success of radical innovation need to across the stage of leading users to mass users (Von Hippel, 2009) ${ }^{[17]}$. because there is not enough maktet conditions to support the new product in China, Firm A opens up the international market with the downstream parteners, finds the lead users of the raidcal innovation product. As Firm A improveing product performance constantly, it expands the share of market of the new product gradually and carry through the "innovation cliff" successfully, and the it leads the technology development of wind power industry.

Radical innovation needs more support from the industry chain than that of incremental innovation (Adner, 2006) ${ }^{[6]}$. Firm A builds a perfect ecological supply chain through choosing suppliers worldwide, fosters and grows up with the supplier to establish cooperation relationship with high quality, all of these are helped to promote the radical innovation performance. Base on the case analysis, this paper proposes the following proposition.

Proposition1: Embedding in global industrial chain has a positive effect on the ability of integrating global industrial chain resources.

Proposition2: The integration of global industrial chain resources includes integrating resource from suppliers technology and the market worldwide; 
Proposition3: The ability of integrating global industrial chain resources has a positive effect on radical innovation performance.

\section{Conclusions}

Although some studies have showed that radical innovation need more support of the whole industry chain from upstream to downstream, but they don't make clearly the challenges from the industry chain when the technical backwardness enterprises making radical innovation will face. At the same time, the impact of network embeddedness on innovation is also controversy. Based on the theory of presupposition in this paper, through a case of china's wind power enterprise, we find it is likely that the embedding in global industry chain affect the radical innovation through the resources integration ability of global industrial chain. The conceptual model of this study shows in Figure 2.

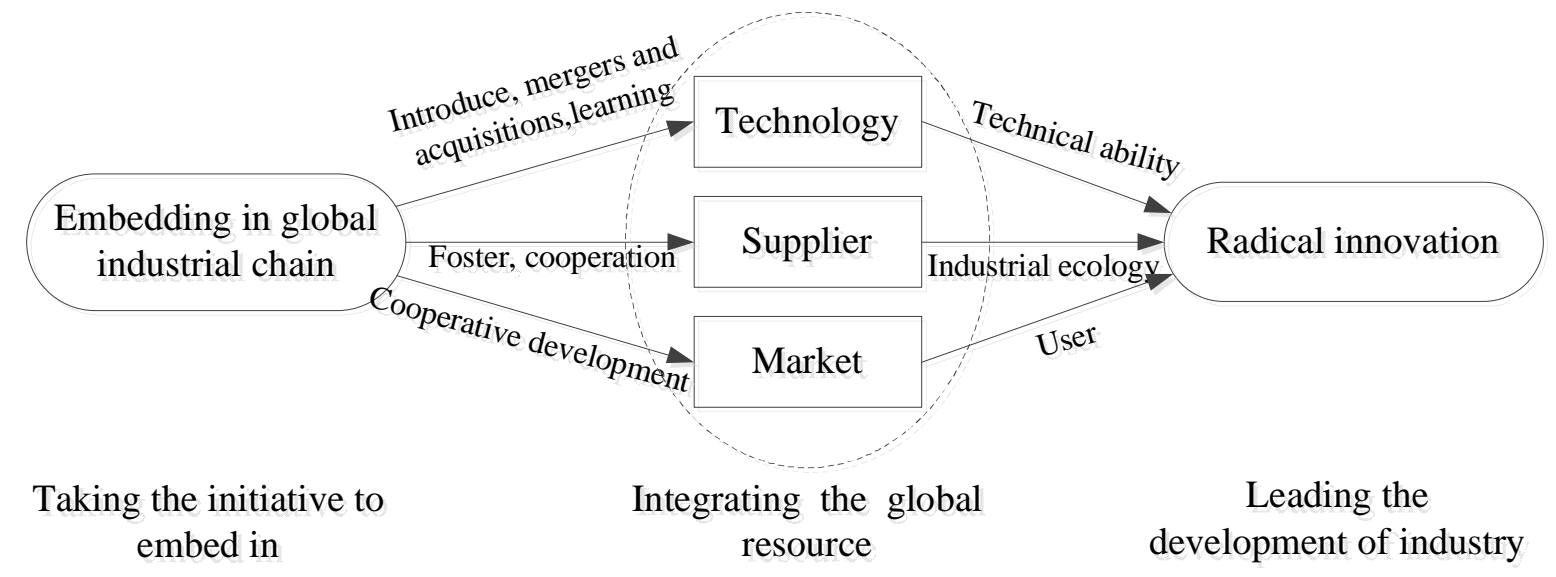

Fig.2 The conceptual model of the study

Firm A can contact and cooperat with the company which holds the forefront technology through embedding in global industrial chain actively, obtains permanent magnet direct-drive technology by means of mergers and acquisitions ultimately, boosts its technical ability and laies the foundation for radical innovation. Radical innovation is the subversion to original technical route, so it can't be successful without the support of new spare and accessory parts. Firm A cultivates its supply chain through direct investment, technology support, strategic cooperation and other modes to build the new industrial ecology which paves the way for its radical innovation. Finally, Firm A exploits the new market through the cooperation with many downstream enterprises to gain the good radical innovation performance.

Of course, due to the special nature of the case study, the conclusion has great limitations to some extent and affects the external validity of the conclusion. It only can preliminary determine the relationship among the variables with the case study, further confirmation on the conceptual model not only need to expound theoretically, but also need to get a more convincing support throug the empirical study of large sample size.

\section{References}

[1] C. Christensen: The innovator's dilemma: When new technologies cause great firms to fail (Harvard Business School Print, America 1997).

[2] T.E. Johnsen:Supplier involvement in new product development and innovation: Taking stock and looking to the future, Journal of Purchasing \& Supply Management Vol.15 (2009), p. 187-197

[3] B.S. Tether: Who co-operates for innovation, and why: An empirical analysis, Research Policy Vol.31 (2002), p. 947-967 
[4] K.J. Petersen, R.B. Handfield and G. L. Ragatz: Supplier integration into new product development: coordinating product, process and supply chain design, Journal of Operations Management Vol.23(2005), p. 371-388

[5] M. Song and A.D. Benedetto: Supplier's involvement and success of radical new product development in new ventures, Journal of Operations Management Vol.26 (2008), p. 1-22

[6] R. Adner: Match your innovation strategy to your innovation ecosystem, Harvard Business Review Vol. 84(2006), p. 98

[7] H.W. Chesbrough: Open innovation: The new imperative for creating and profiting from technology (Harvard Business Press, America 2003).

[8] J. West and S. Gallagher: Challenges of open innovation: the paradox of firm investment in open-source software, R\&D Management Vol. 36(2006), p. 319-331

[9] B. Uzzi: Embeddedness in the making of financial capital: How social relations and networks benefit firms seeking financing, American Sociological Review Vol. 64(1999), p. 481-505

[10] M. Bengtsson and Ö. Sölvell: Climate of competition, clusters and innovative performance, Scandinavian Journal of Management Vol. 20(2004), p. 225-244

[11]X.B. Wu and Y. Wei: The analysis of relational embeddeness on strategic networks of technology innovation in Chinese pharmaceutical firns, Studies of science of science Vol.23(2005), p. 561-565

[12]T. Rowley, D. Behlens, and D. Krackhardt: Redundant governance structures: Ananalysis of structural and relational embeddedness in the steel and semiconductor industries, Strategic Management Journal Vol. 21(2000), p. 369-386

[13] K.M. Eisenhardt: Building theories from case study research, Academy of management review, Vol. 14(1989), p. 532-550

[14]A. Yan and B.Gray: Bargaining Power, Management Control, And Performance In United States-China Joint Ventures: A Comparative Case Study, Academy of Management journal, Vol. 37(1994), p. 1478-1517

[15]R.K. Yin: Case study research: Design and methods, 3rd edn, Applied Social Research Methods Series, Vol. 5 (2003), p. 19-56

[16]J.B. Barney, in: Arikan A M. The resource-based view: Origins and implications. edtied by M.A. Hitt, R.E. Freeman and J.S. Harrison, Handbook of strategic management Oxford: Blackwell, (2001), in press.

[17]E.Von Hippel: Democratizing innovation: the evolving phenomenon of user innovation, International Journal of Innovation Science Vol. 1(2009), p. 29-40 